\title{
Crown Ether Schiff bases and their Complexes: Recent Advances (A Review )
}

\author{
KHALID MAHER ${ }^{\star}$ and SHIREEN MOHAMMED \\ Department of Chemistry, College of Science, Zakho University, Kurdistan, Region, Iraq. \\ *Corresponding author E-mail: maher-333@ hotmail.de \\ http://dx.doi.org/10.13005/ojc/340402
}

(Received: June 25, 2018; Accepted: Junly 17, 2018)

\begin{abstract}
In recent years, an interest in the synthesis of crown ether Schiff bases and their complexes has been increased, due to the significance and broadly the uses of these compounds in various fields. The present review paper outline extensive recent advances literature survey on the crown ether including azomethine group and their complexes with the tough and easy granter atoms, has been reconsidered. Emphasis has been done on element complexation with crown ether holding Schiff bases to enable the researchers to procure valuable information of the chelating activity of crown ether containing azomethine group and their enforcement.
\end{abstract}

Keyword: Schiff bases, Complexes, Synthesis, Crown Ethers, Azomethine linkages.

\section{INTRODUCTION}

The first set of crown ethers compounds prepared by Pedersen assumes an essential part in the growth of supramolecular chemistry ${ }^{1-4}$. In the area of supramolecular chemistry, crown ethers are suited to the gathering of most famous host group, since their implication complexes supply high practical applications ${ }^{5-6}$. Macrocycles offer the thrilling potential to build supramolecular congregations that are fit for performing very particular atomic capacities. Molecular enforcement through these composition and their geustes, essentially transition elements ions or bio-molecules (nucleic acids, proteins, etc.), supply a high chance for seeking key side of supramolecular chemistry, which are also considered in a diversity of directions including, biology, medicine, physics, chemistry and related science and technology ${ }^{7-9}$. The best notable character of crown ethers is their potential to obtain compounds electively with ionic hosts, such as cations of elements of the first group and the second group of periodic table, the various crown ether hole bulk can be elected to coordinate selectively with a given cation ${ }^{10}$. Crown ether ligands with extra donor atom in the side chain have been prepared orderly to vary the ion bonding capability, sensitivity and selectivity of the origin crown ethers. Crown ethers ${ }^{11-13}$ along with Schiff base ${ }^{14-16}$ consideration of coordination chemists. Collection of these fractions in 
one molecule superiority to ambis-dentate chelating systems able to figuration of both coordinate with $d$ metals of intermediate hardness $\left(\mathrm{Ni}^{+2}, \mathrm{Zn}^{+2}, \mathrm{Cu}^{+2}\right)$ coordinating via the azomethine part and crown ether complexes with toughs s-metal ions $\left(\mathrm{Li}^{+}, \mathrm{K}^{+}\right.$, $\left.\mathrm{Na}^{+}, \mathrm{Ba}^{+2}\right)^{17,18}$. The coordination with $\mathrm{d}$ and $\mathrm{s}$ metals can be complete effectively in various arrangements to produce single- and di-nuclear compounds. The steadiness of the generate Macrocyclic metal buildings influenced basically by a few variables including the symmetry of the crown ether, the unit and sort of donners show in the ligand, variety and helpful impacts of neighbouring restricting destinations, relative size of the metal particle as for the crown ether hole estimate, the sign on the ion, adaptation of the ether cycle, the specific framework of the outlined ligands, their comparative location inside the macrocyclic shell, number and space of the coordinated cycle framed on complexation and the dissolvable, it is additionally conceivable to tailor-make distinctive kinds of atoms for particular uses, ion selective electrodes ${ }^{19}$ and in photosensitive frameworks ${ }^{20,21,22}$. The specific capacity of crown ethers to complex cations ${ }^{23}$ has been utilized to survey an extensive number of uses, for example, the creation of sensors and the particular removing of cations or the ionic transmit in velums ${ }^{24}$. Crown ethers-containing Schiff bases are surveyed deficiently ${ }^{25-28}$. Since these ligands are imperative for the advancement of chemosensors and photograph triggers, and also for extraction of particles ${ }^{1,2}$. Polyfunctional materials synthesized on the principle of metal buildings of azomethines ${ }^{29-32}$ are appeared by luminescent ${ }^{33-35}$ and magneto dynamic ${ }^{36,37}$ materials, catalysts $^{38}$, sensors ${ }^{39-41}$, metal-containing polymers ${ }^{42}$. In recent years, there has been a major attention in the chemistry of antipyrine Schiff base crown ether ${ }^{43-45}$. Crown etherazomethine group of 4-antipyrine and its buildings have an assortment of utilization in the natural, clinical, logical and pharmacological regions ${ }^{46}$. Despite the fact that ambidentate ligands were analyzed in various investigations, just a single report has given an account of benzo-crown ether-4-antipyrine containing Schiff bases ${ }^{47}$.

\section{Aza-Crown Ether Schiff base}

In recent years an interest in the research of aza-crown ethers containing azomethine groupmetal complexes have been increased. Essentially, Crown ethers utilize as the substituents have encounter considerable interest, because of their coordinating capability to ions and specific arranging. Wei and his co-workers prepared some aza-crown ether containing single and di-azomethine groups (Scheme 1), orderly to examine the action of the aza-crown ring have stereo arranging an assignment on diver's remarkable characteristic, namely, the strength for complexation with the metal ion and bio-mimetic performance ${ }^{48}$.

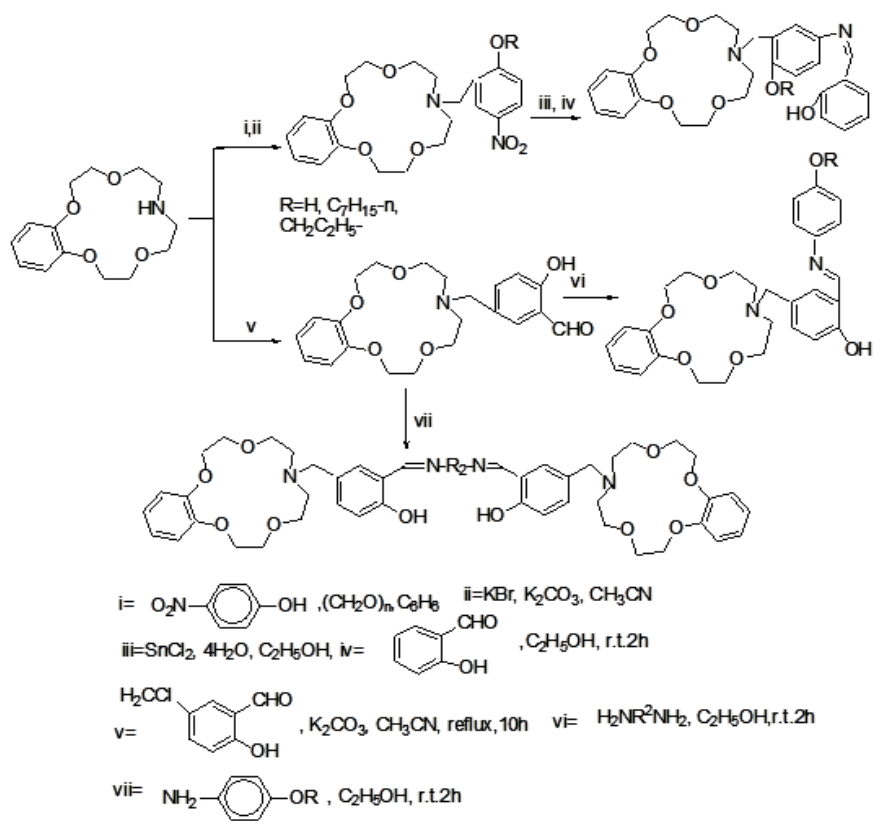

Scheme 1. Preparation $\mathbf{n}$ of Aza-crown ether holding mono and azome ethane gathering. 
$\mathrm{Lu}^{49}$ and co-workers 2003 has been effectively prepared a range of Cobalt(II) complexes with aza-crown ether exhibit salicylaldimine azomethine moiety (Figure 1).
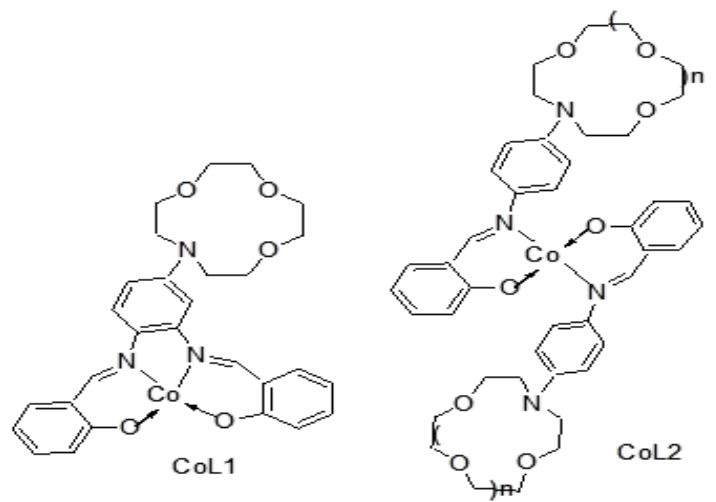

Fig . 1. Cobalt (II) Complexes of Aza-crown ether Schiff Bases ligand

The cation chelating quality of the complexes and the steadiness constant with first and second metal cation have been studied. The synthesis of aza-crown ether Schiff bases illustrated in (Scheme 2,3 and 4).

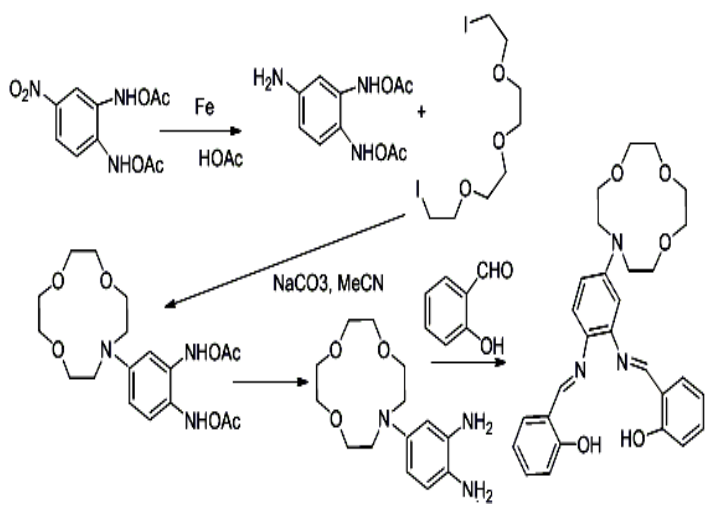

Scheme2. Route Scheme of Synthesis of H2L1 ligand

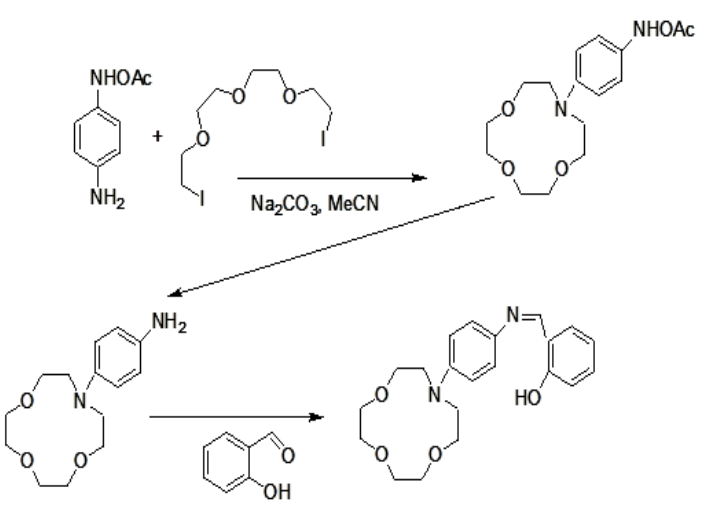

Scheme 3. Preparation of ligand HL2

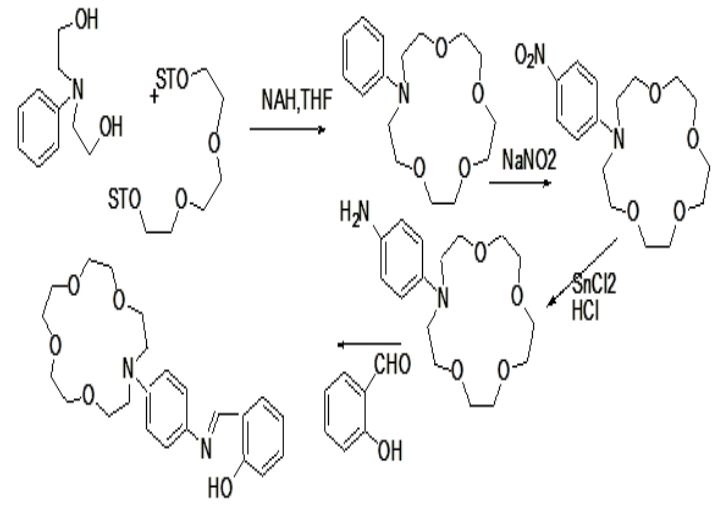

Sheme 4. Route Scheme of Synthesis of HL3 ligand

Dioxygen consanguinity of azomethine Cobalt (II) Complexes with aza-crown ethers have been reported by Lij ${ }^{50}$ and co-workers 2010 . Set of aza-crown ether Schiff bases were synthesized (Fig. 2). The result of the study shows that the existence of a pendant crown ether gathering in the imine ligand remarkably evolves the $\mathrm{O}_{2}$ binding abilities of the complexes.

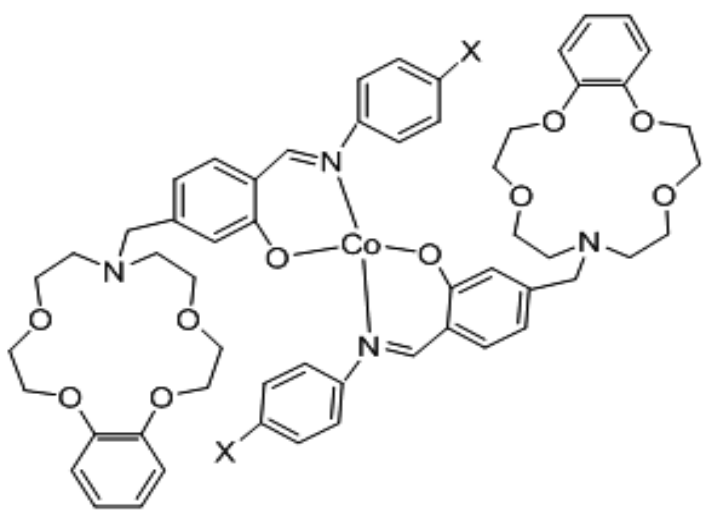

Fig. 2. The Structure of Schiff Base Cobalt (II) Complexes

New salicylaldimine mono-Schiff bases with aza-crown pendant have been produced by condensing reaction of 3-[(benzo-10-aza-15crown-methyl] salicylaldehye with substituted aniline (Scheme 5). The action of the coordination aza-crown ether moiety in the complexation with metal ions have been studied ${ }^{51}$.

Furthermore, work in Synthesis of $\mathrm{N}$-(4-Salicylideneiminoaryl) mono aza crown ethers and Dioxygen consanguinity of their cobalt (II) compounds have been provided by Zeng et al., 2003. The authors of this research designed and synthesized N-pivot lariat ethers with azomethine gathering as side chain, and predictable their cobalt (II) compounds to have enhanced dioxygen consanguinity ${ }^{52}$ (Scheme 6) and (Fig. 3). 


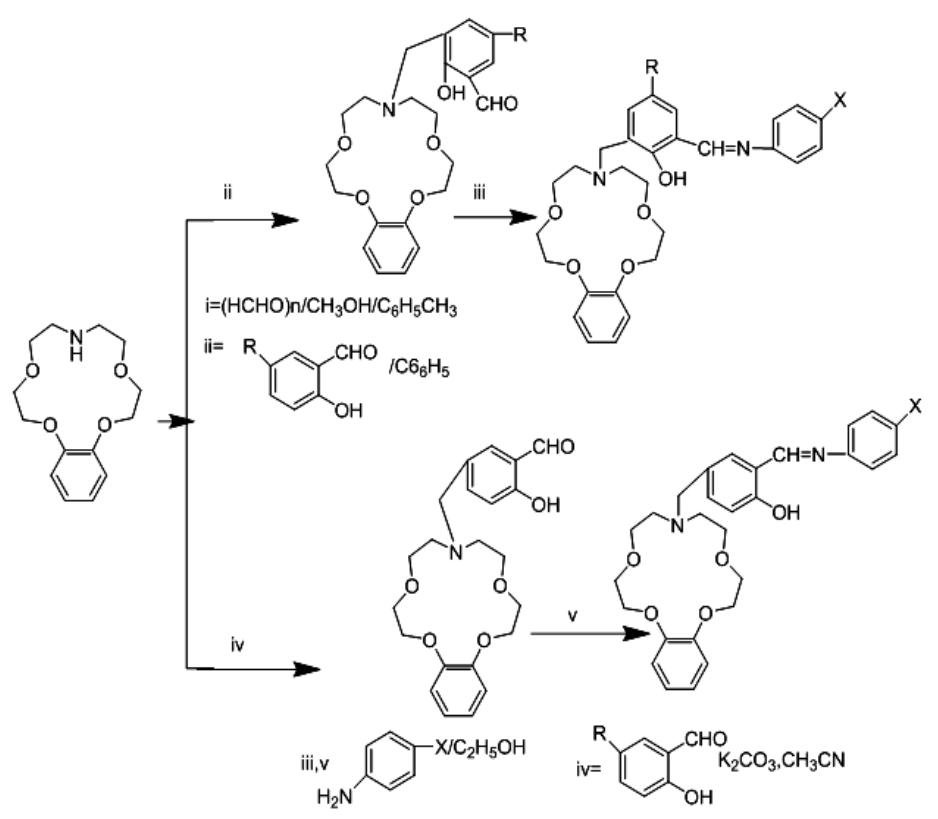

Sheme 5. Preparation of Salicylaldimine ligands

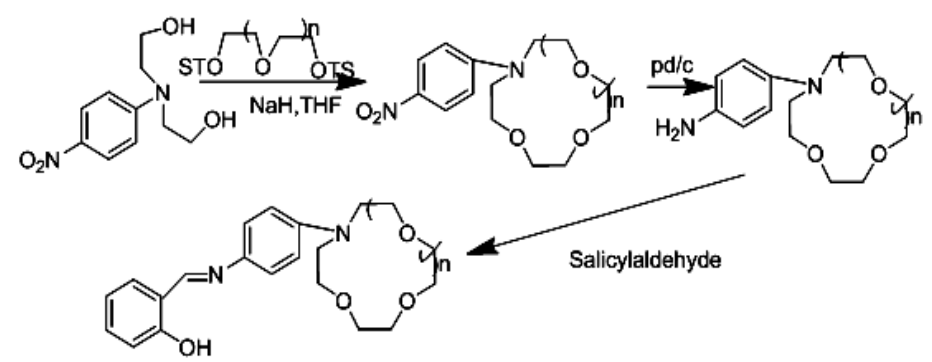

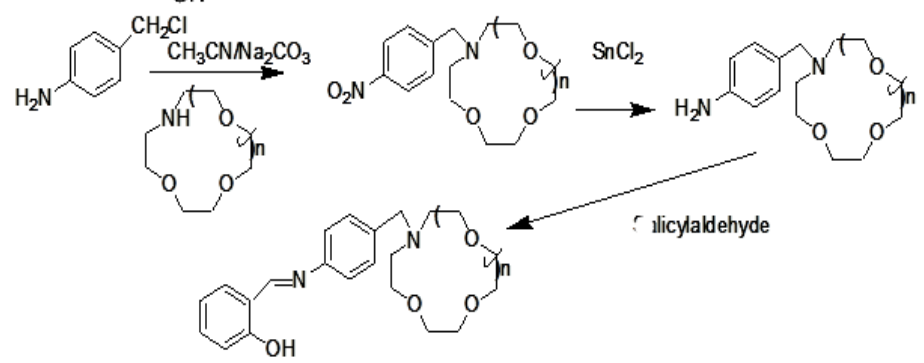

Scheme 6. The synthetic route and structure of synthesized Schiff base crown ether

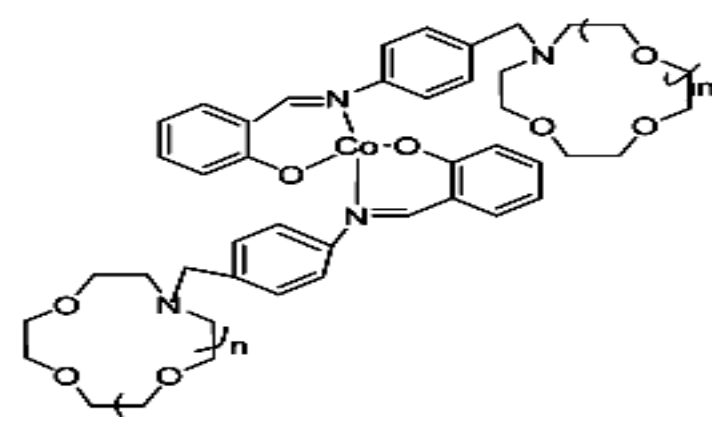

Fig.3. The structure of cobalt complexes

More searching about the preparation of Azacrown Ether-substituted Mono-imine and Dioxygen consanguine of their Co (II) Complexes carried out by Wei 2004 . The effect of the substituted aza-crown rings and their binding sites on dioxygen affinities of the Cobalt (II) complexes were discussed and compared with that of crown free analogues ${ }^{53}$ (Figure 4).

Novel Series of mono-azomethine group crown-ether and their metal compounds has been 
synthesized (Fig. 5), and their catalytic execution in PNPP hydrolysis, and the kinetics and the mechanism of PNPP catalytic hydrolysis in buffer solution have been investigated ${ }^{54}$.

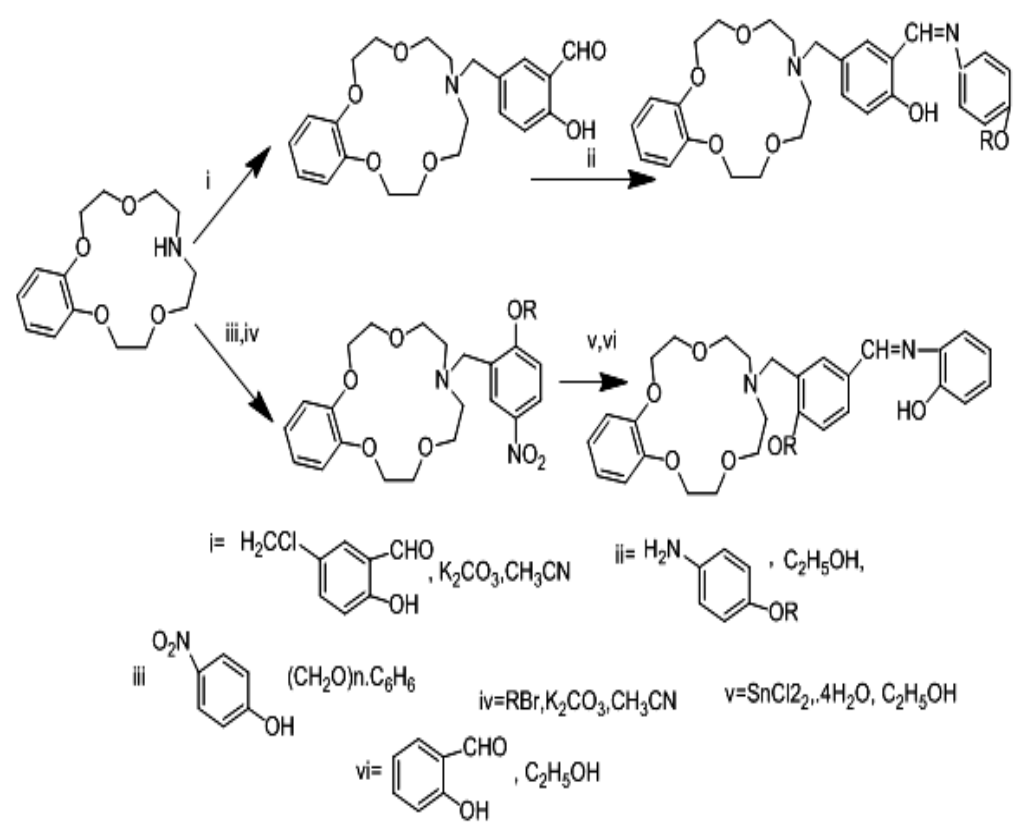

Fig. 4. The Aza-crown ether substituted salicylaldimine mono azomethine moiety

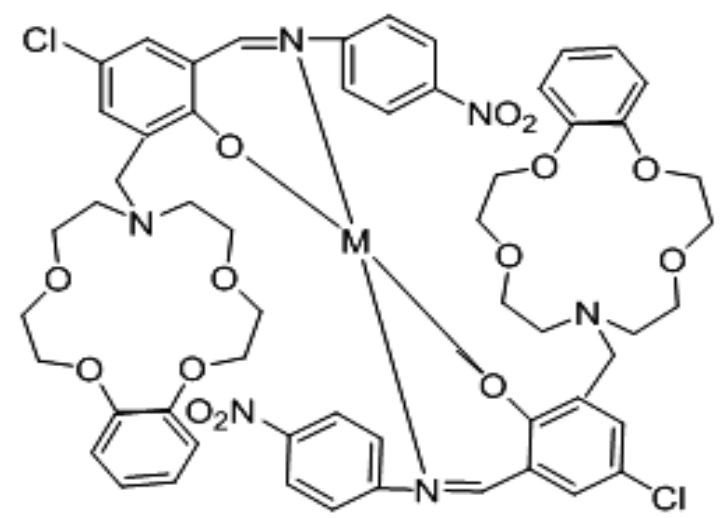

Fig. 5. The structure of azomethine compounds

Cobalt (II) Salen Compounds with diazacrown pendants were perfectly prepared beginning with benzo-10-aza-15-crown-5(Scheme 7) and (Figure 6).

The modification of $\mathrm{O}_{2}$ binding abilities by pendant substituents was studied, and contrast with the origin azomethine gathering compounds $\mathrm{CoL}_{1}$ (Co Salen). The results signalizes that the dioxygen consanguine of CoL has been highly promoted by aza-crown pendants compared with that by morpholino pendants, and the $\mathrm{O}_{2}$ linking abilities of $\mathrm{CoL}_{1}$ and $\mathrm{CoL}_{2}$ with aza-crown pendants will also be promoted by insert alkali metal cations ${ }^{55}$.
The complexation of a set of novel azomethine compounds holding the N-phenylaza15-crown-5 moiety with first and second groups of periodic table metal ions (incl. $\mathrm{Be}^{+2}$ and $\mathrm{Mg}^{+2}$ ), was prepared (Fig. 7) by Antonov and their co-workers 2001. The position of the N-phenylaza-15-crown-5 moiety in the ligand structure and the properties of the metal ion was studied ${ }^{56}$.

New uniform di-azomethine group $\mathrm{Mn}$ (III) and $\mathrm{Co}$ (II) compounds with benzo-10-aza-crown ether pendants $\left(\mathrm{MnL}_{1} \mathrm{Cl}, \mathrm{CoL}_{1}\right)$, and their similarities with morpholino pendants $\left(\mathrm{MnL}_{2} \mathrm{Cl}, \mathrm{CoL}_{2}\right)$, have been prepared and utilized as design to imitative hydrolase in p-nitrophenyl picolinate by Li and Co-workers 2006 (Scheme 8).

Furthermore, the effect of temperature on the synthesized complexes signalizes that compounds are stead in the domain of the temperature studied in the work ${ }^{57}$.

Khandar 2007 reported the preparation of $\mathrm{Ni}$ (II) compounds 16-membrane mixed-donor macrocyclic azomethine ligand, potentially hexa-dentate, holding two pendant alcohol groups 
(Scheme 9). The Ultra-violet and Visible spectroscopy, conductivity determination and $\mathrm{X}$-ray limitation show that the compounds are a distorted octahedral shape $^{58}$.

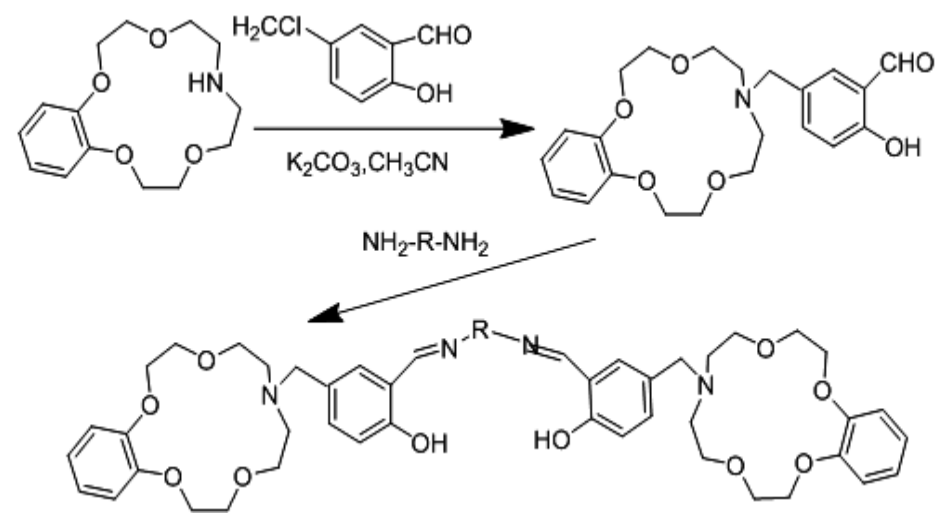

Scheme 7. The synthetic route and structure of synthesized Schiff base crown ether ligand

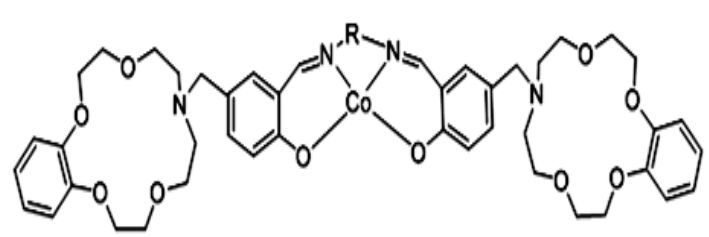

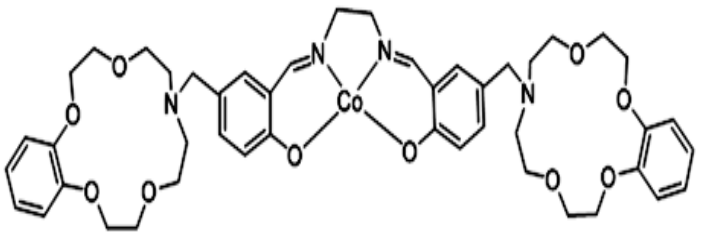

Fig. 6. The structure of CoL Comples<smiles>[X][Y]1ccc([R])cc1</smiles>

1. $\mathrm{X}=\mathrm{N} ; \mathrm{Y}=\mathrm{CH} ; \mathrm{R}=\mathrm{H}$

2.X=N; $\mathrm{Y}=\mathrm{CH} ; \mathrm{R}=\mathrm{N}\left(\mathrm{CH}_{3}\right)_{2}$

$1^{*} . X=\mathrm{CH} ; Y=\mathrm{N} ; \mathrm{R}=\mathrm{H}$

$2^{*} . \mathrm{X}=\mathrm{CH} ; \mathrm{Y}=\mathrm{N} ; \mathrm{R}=\mathrm{N}\left(\mathrm{CH}_{3}\right)_{2}$

$3^{*} . \mathrm{X}=\mathrm{CH} ; \mathrm{Y}=\mathrm{N}, \mathrm{R}=\mathrm{NO}_{2}$

Fig. 7. The structure of Schiff base crown ether ligand

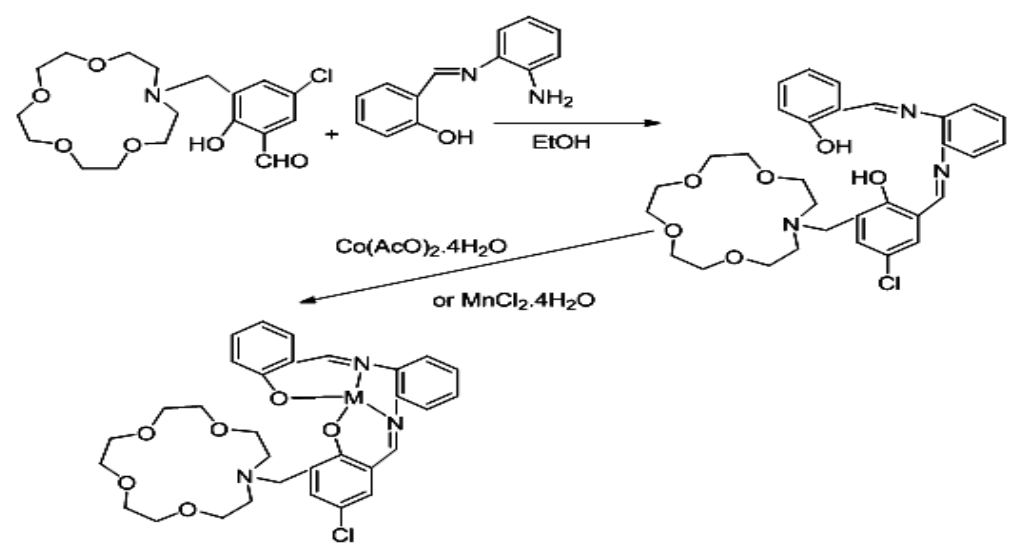

Scheme 8. Preparation Route and skeleton of un-uniform of azomethine complexes

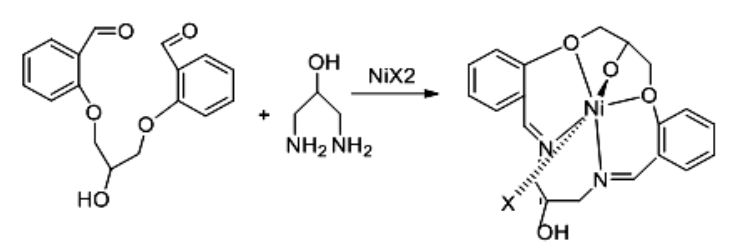

Scheme 9. The synthesis and structure of $\mathrm{Ni}(\mathrm{II})$ complexes

Cupta et al., 2010 reported the preparation of novel azomethine lariat ether binding based on 4,13-diaza-18-crown ether. The prepared ligand was the scout as a neuter ionophore for producing poly vinyl chloride based membrane sensors selective to silver ${ }^{59}$ (Figure 8). 
<smiles>[R]N=Cc1ccc(CN2CCOCCOCCN(Cc3ccc(C=O)cc3)CCOCCOCCN(Cc3ccccc3)CCOCCN(Cc3ccc(C=O)cc3)CCOCCOCCN(Cc3ccc(C=N)cc3)CCOCCOCC2)cc1</smiles>

Fig. 8. Structure of the prepared ligand

Condensing of 4,4-difluoro-4-bora-3a,4adiaza-s-indacene as a fluorophore connected at the 3-location to an $\mathrm{N}$-thia macrocycle to an ethenylphenyl binder was provided by Isaad et al., 2013 to obtain the water-soluble Chemosensor16 (Figure. 9).

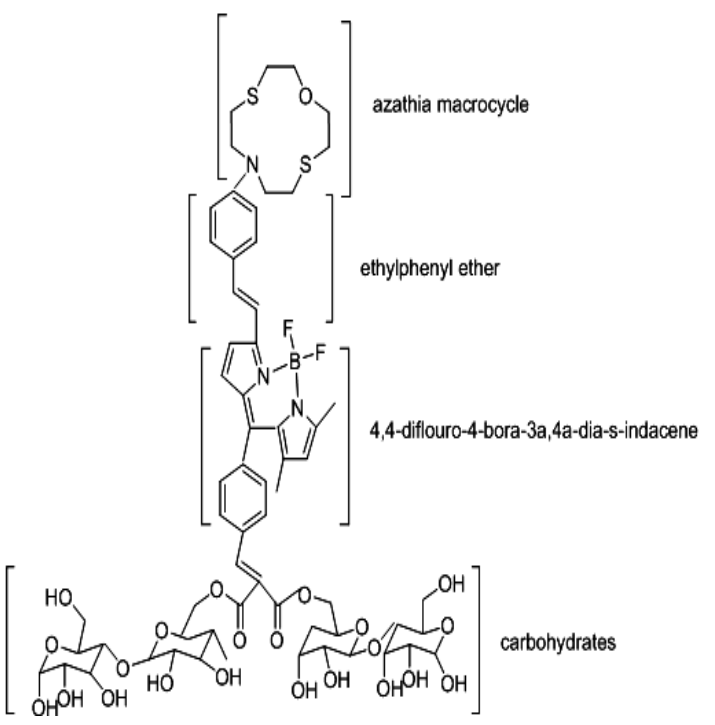

Fig. 9. The General skeleton of the chemosensor ligand
The synthesized Chemosensor was used as electro-electrode for uncovering $\mathrm{Hg}^{+2}$. Chemosensor 16 display noteworthy high ability to distinguish between $\mathrm{Hg}^{+2}$ and structurally similar ions in coupling with a visible colorimetric and fluorometricchange ${ }^{60}$.

\section{Aza-Crown Ether Schiff Base as Catalyst}

Zeng et al., 2002 reported the preparation of Schiff base group containing aza-crown ether cycle and their transition elements compounds. The produced complexes were identified using different spectroscopy methods. The prepared Schiff bases were used as catalytic oxidation. They found that aromatic ring moiety in crown ether observed remarkably dioxygen affinities and biomimetic catalytic compared to uncrowned moiety ${ }^{61}$ (Scheme 10).

More investigations about the synthesis of azomethine containing aza-crown ether cycles were provided. Zeng et al., 2006 reported the synthesis of salicylaldimine imine containing aza-crown ether cycle and their Mn (III) metal complexes (Figure 10).

The prepared imine complexes were examined for their catalytic oxidation of styrene, they found that adding of the element of the first and the second group of periodic elements to the oxidation system increases the transformation of styrene to benzaldehyde ${ }^{62}$

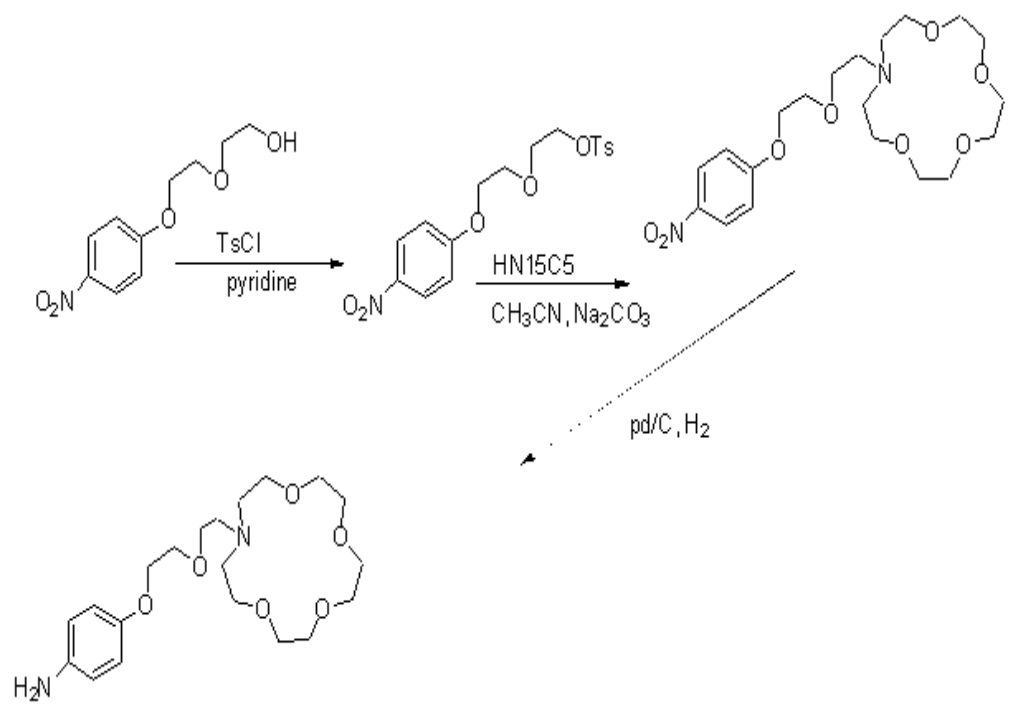

Scheme 10. Route for the key intermediate ligands 


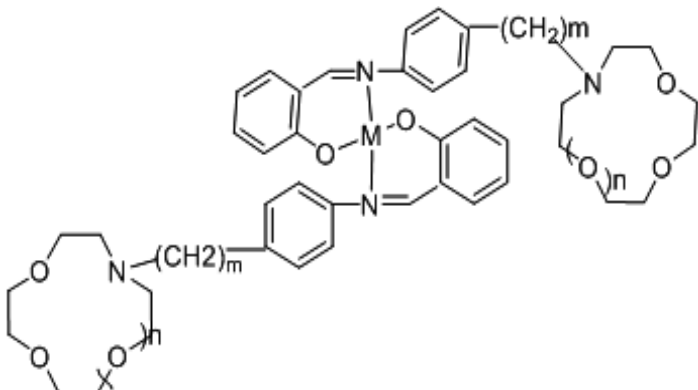

Fig. 10. The structure of Mn(II)azomethine ligands and their complexes

A set of new unsymmetrical azomethine manganese (III) compounds with morpholino moiety have been prepared and investigated as catalysts in the respiratory oxidation of xylene to toluic acid (Scheme 11).
The investigation illustrated that elective oxidation of para-xylene to para-toluic acid can effectively happen in the existing of azomethine Mn (III) complexes with pendant aza-crown group, which show a more best catalytic action than the azomethine Mn (III)compounds with pendant morpholino groupdo ${ }^{63}$.

Investigating the continuity of oxygenation and catalytic oxidation, Zeng et al., 2004 reported the synthesis of mono-Schiff base containing crown ether cycles and their metal complexes (Fig. 11). The result of the study concluded that the azomethine compounds holding crown ether cycles effected on the dioxygen affinities and biomimetic catalytic oxidation $^{64}$.

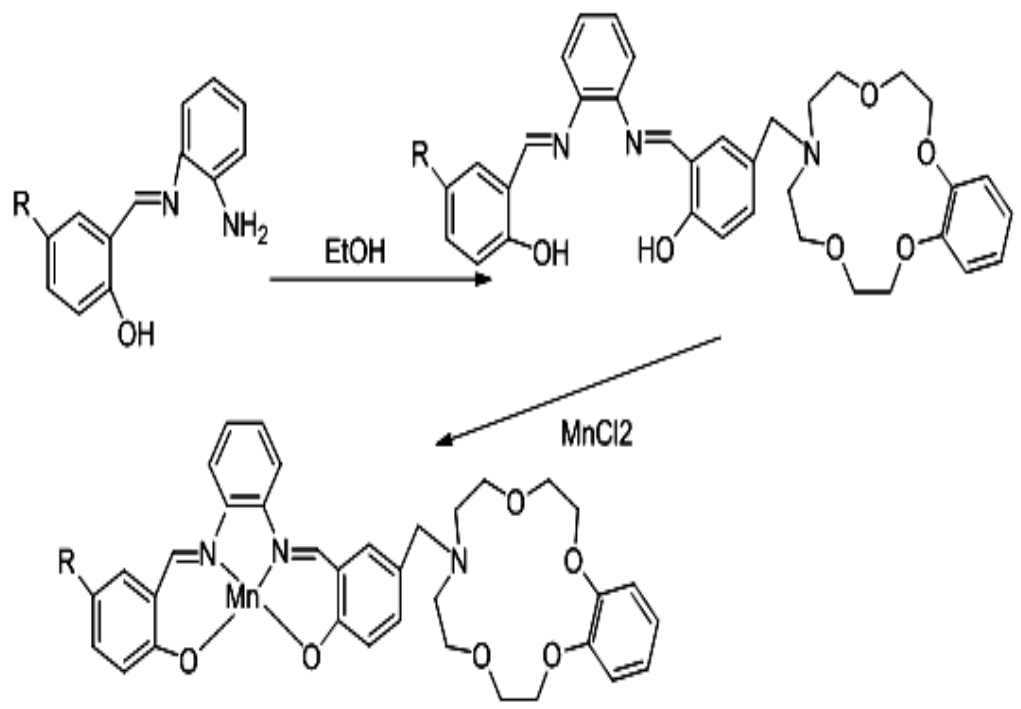

Scheme 11. The Route for the preparation and the skeleton of unsymmetrical azomethine compounds

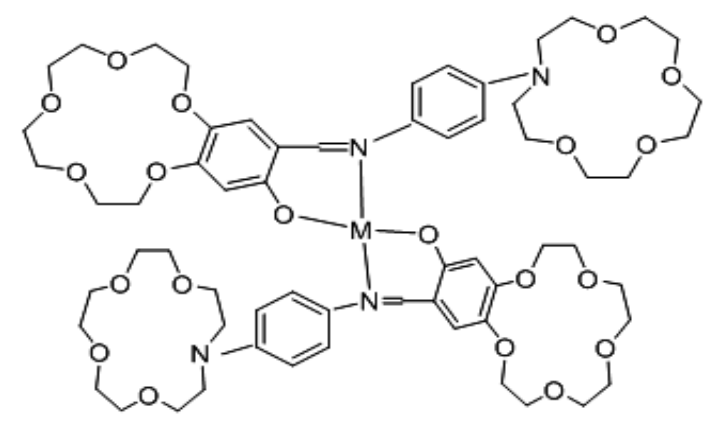

Fig. 11. The Skeleton of crown ether complexes

$\mathrm{Li}^{65}$ and his research team 2006, reported the synthesis of novel mono-azomethine cobalt complexes containing aza-crown moiety. The influence of Crown ether on the adjustment, of $\mathrm{O}_{2}$ coordinating ability and the catalytic oxidation of styrene were studied. The conclusion suggests that the dioxygen consanguine of the cobalt complexes are too high performances by aza-crown pendants than that with morpholino pendants, and the $\mathrm{O}_{2}$ linking abilities of cobalt complexes with aza-crown pendants can also be promoted by inserting alkali metal cations (Figure 12).

More works about the preparation of new mono azomethine $\mathrm{Mn}$ (III) Compounds containing aza-crown moiety have been provided by Yan et al., 
2006. The synthesized Complexes are used as catalyst in the respiratory oxidation of 4-xylene to 4-toluic acid (Scheme 12). Result of the study indicates that in the inserting of alkali metal addition the transformation of 4-xylene to 4-toluic acid ${ }^{66}$.

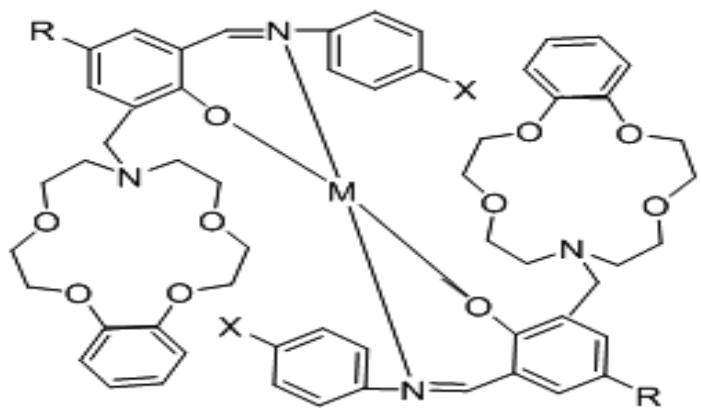

Fig. 12. The structure of azomethine compounds

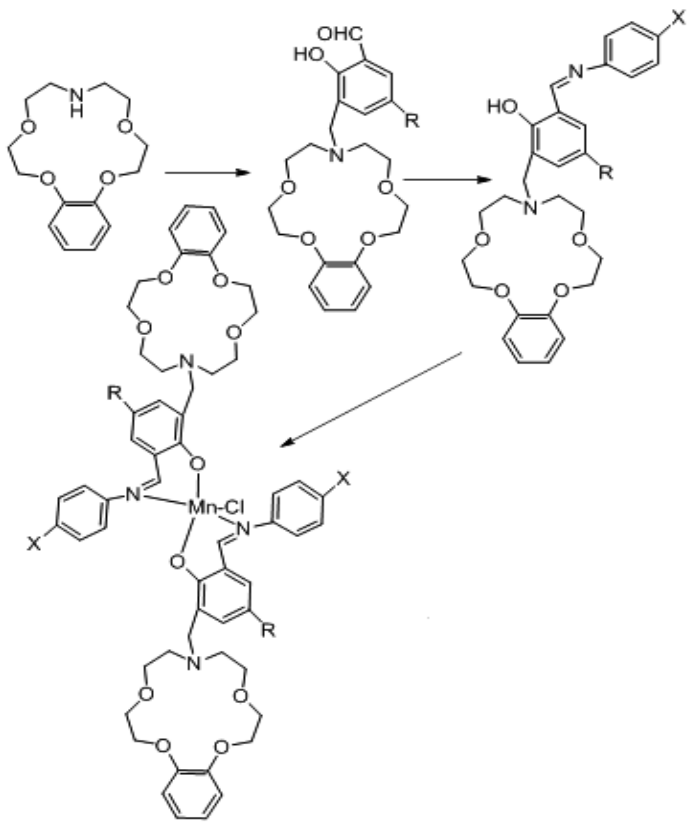

Scheme 12. The route for the preparing of azomethine Mn(III) compounds

A set of new aza-crown ether azomethine have been prepared and their host-guest complexation with $\mathrm{C}_{60}$, have been investigated in toluene using absorption spectroscopic method ${ }^{67}$. All Produced compounds show stable complexes with 1:1 stoichiometry (Scheme 13).

New complexes from cobalt(II) and manganese (III) with aza-crown ether containing salen and salophen substituents were prepared beginning from benzo-10-aza-15-crown-5
(Fig. 13). The adjustment of $\mathrm{O}_{2}$ binding abilities and catalytic oxidation by these pendant substituent's in the complexes were studied and resemble with the complexes $\mathrm{ML}_{5}$ and $\mathrm{ML}_{6}$. The results point out that the dioxygen consanguine and catalytic oxidation affectivity of these complexes have been

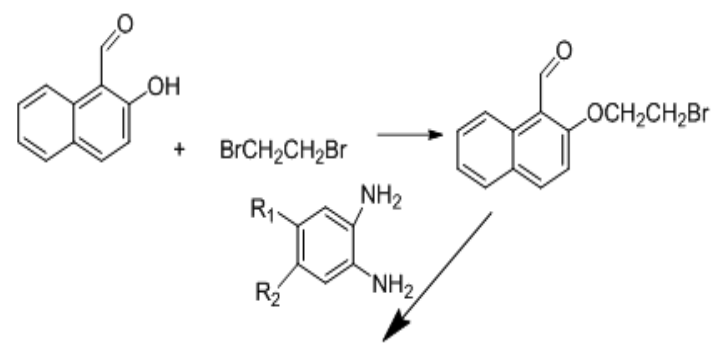

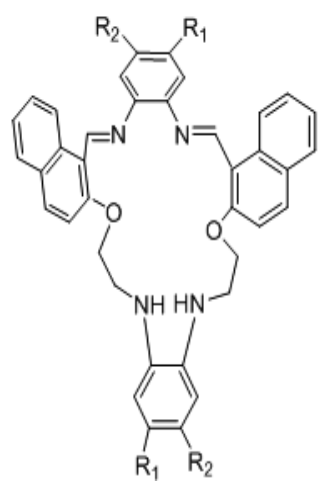

Scheme 13. Synthesis of Macrocyclic Compounds

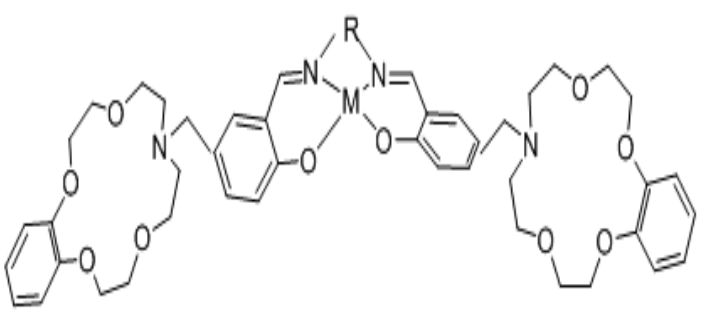

Fig.13. Synthesis of Complexes from Co(II) and Mn(III) highly increased by aza-crown pendants than by morpholino pendants ${ }^{68}$.

Sousa ${ }^{69}$ etal., 2004, reported the synthesis of $\mathrm{Ni}$ (II) and $\mathrm{Cu}$ (II) complexes with azomethine holding aza-crown and two benzo-15-crown-5 moieties as elastic branches. The synthesized complexes were identified using different spectroscopies method (Scheme 14).

Novel azomethine $\mathrm{Mn}$ (III) and cobalt(II) compounds with each of benzo-10-aza-crown ether 
pendants $\left(\mathrm{MnL}_{1}, \mathrm{CoL}_{1}\right)$ or morpholino pendants $\left(\mathrm{MnL}_{2} 2 \mathrm{Cl}, \mathrm{CoL}_{2}\right)$ have been utilize das patterns for hydrolase enzymes by mediate the kinetics of their hydrolysis reactions with $\mathrm{p}$-nitrophenyl picolinate (PNPP)(Scheme 15) (Fig. 14). Result of the study described the effect of $\mathrm{pH}$ on the average of catalytic PNPP hydrolysis, which increased by increasing $\mathrm{pH}^{70}$.

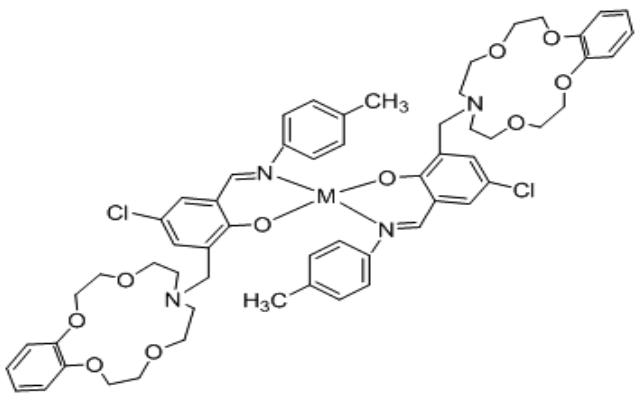

Fig. 14. The structures of the Schiff base complexes

Novel mono-azomethine $\mathrm{Mn}(\mathrm{III})$ and cobalt(II) complexes with benzo-10-aza-crown ether pendants $\left(\mathrm{MnL}_{1}, \mathrm{CoL}_{1}\right)$ and morpholino pendants $\left(\mathrm{MnL}_{2} 2 \mathrm{Cl}, \mathrm{CoL}_{2}\right)$ were prepared and utilized as patterns for hydrolase enzymes to enhance the hydrolysis of $p$-nitrophenyl picolinate (PNPP) in the buffered CTAB solution (Fig. 15). The result of the study indicates that In differentiation, with the non-crowned compounds, the crowned azomethine compounds display higher catalytic effectiveness or enhance PNPP hydrolysis ${ }^{71}$.

$\mathrm{Hu}$ et al., 2010, illustrated the synthesis of two new cobalt(II) complexes of the azomethine containing aza-crown moiety (Fig. 16). The prepared Schiff base complexes were investigated by the action of surfactant micelles on the activity of the hydrolysis of PNPP. The result appears that the azomethine cobalt (II) compounds and their metallo-micelles as hydrolase imitate display useful catalytic effective and identical catalytic properties to normal enzyme ${ }^{72}$.

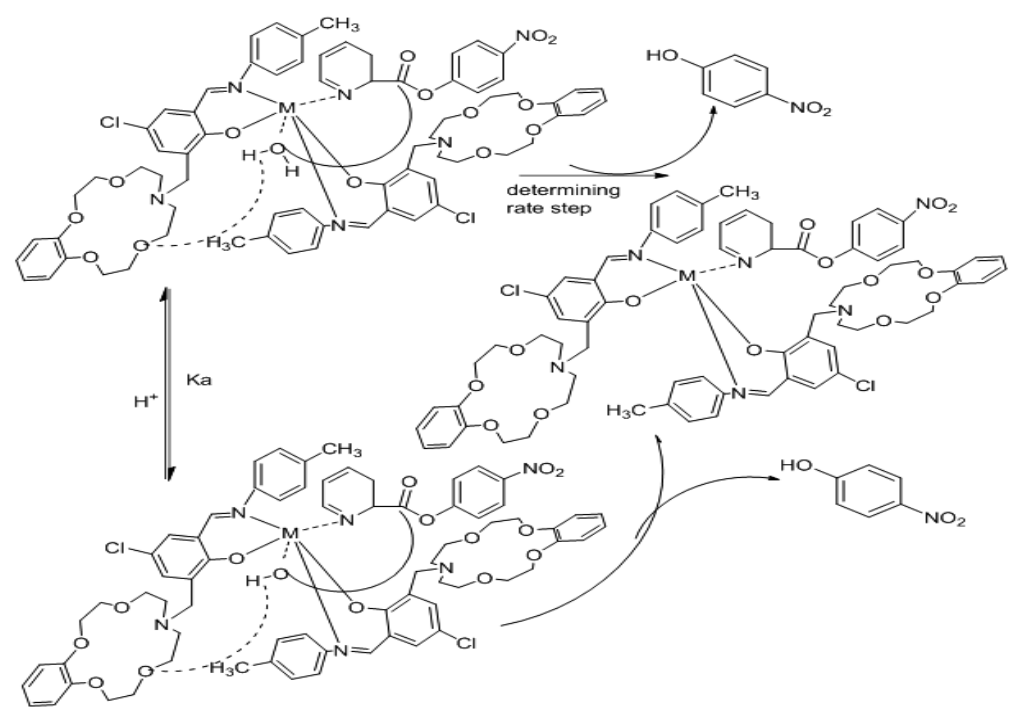

Scheme. 15. The process of proton transfer at the step of the rate determining<smiles>O=[N+]([O-])c1ccc(N2Oc3c(CN4CCOCCOc5ccccc5OCCOCC4)cc(Cl)cc3N(c3ccc([N+](=O)[O-])cc3)Oc3c(CN4CCOCCOc5ccccc5OCCOCC4)cc(Cl)cc32)cc1</smiles>

Fig.15. The skeleton of prepared mono-Azomethine

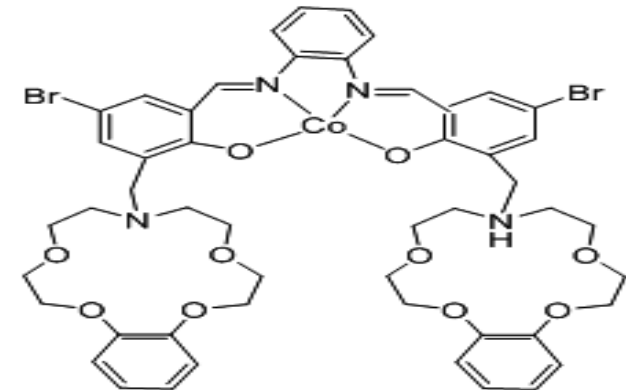

Fig. 16. The structure of the complexes 
Novel cobalt compounds with N-crown ether azomethine containing substituted salicylaldimine were prepared and utilized as design to imitate hydrolase in catalytic hydrolysis of the ester (Fig. 17).kinetic mechanism of PNPP hydrolysis have been studied. The kinetic mathematical design for PNPP cleavage catalyzed by the cobalt compounds has been suggested. The result indicates that the bis(aza crown ether) c obalt complexes show more activity in the PNPP catalytic hydrolysis ${ }^{73}$.
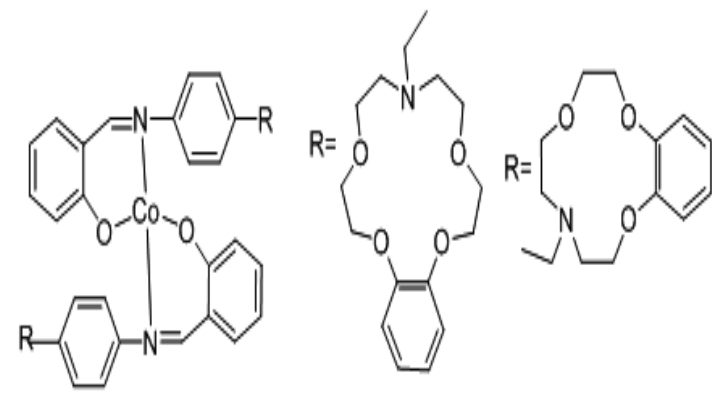

Fig.17. The Structure of Complexes

\section{Crown ether containing azomethine groupand their Metal Complexes}

Novel Mn (II) azomethine complexes group $\mathrm{N}$-crown ether were prepared and identified using spectroscopy methods. The prepared complexes were used as catalysts for oxidation of cyclohexene and cyclo-octene by oxone (Scheme 16). The action of crown-ether cycle connected to imine catalysts on the qualification of these catalysts was examined, the catalytic performance of these catalysts arises when an aromatic azo-base were added to the reaction ${ }^{74}$.

Kandaz et al., reported the synthesis of new soluble symmetrical phthalocyanine containing macrocycles (Scheme 17). The synthesized ligands were characterized using different spectroscopy methods. The author of this work achieved success in alkali-metal binding to the endocyclic cap of crown ether by metal-ion ${ }^{75}$.

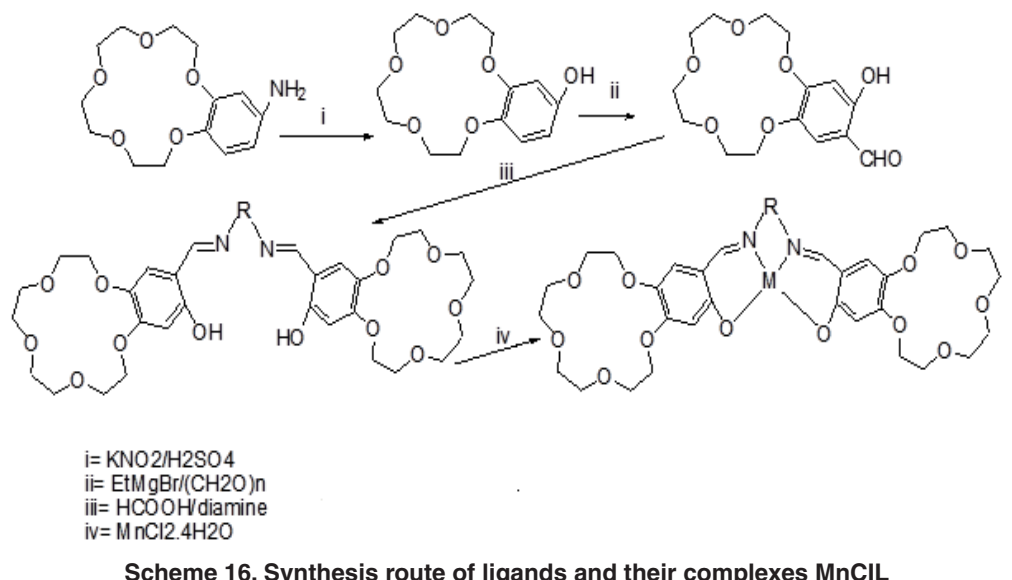

Parkin and Menon ${ }^{76}$ reported novel crown ether azomethine synthesized from the reaction of different aldehydes with di-amino-18-crown-6. The compounds which have been separated were purified and identified using various Spectroscopy method. All prepared Compounds appear liquid crystal properties.

Zinc complexes of crown azomethine were synthesized and characterized using various Method of analysis (Scheme 18). The data of analysis indicate that in correspondence with the notion of hard and soft acids and bases, the hard lithium cation bonded to the crown moiety with the figuration of mono- (Li) and binuclear (Li, Zn) complexes ${ }^{77}$.
Safin et al., 2012, reported the preparation of 15-Crown-ether-exhibit $\mathrm{N}$-salicylidene aniline compounds by reacting of 4-amino-15-crown-5 with salicylaldehyde (Fig. 18). The produced crown ether Schiff base was characterized using a different method of analysis. In addition of that, the optical properties of ligands were investigated ${ }^{78}$.

Jogani et al., 2000, reported the preparation of a bi-branches crown ether possessed of two cation binding side chains containing an azomethine chelating derived from the reaction of crown ether, I8-crown-6 with aldehyde (Scheme 19) (Fig. 19). The complexes of azomethine with metal ions have been prepared and their chelating action was investigated $^{79}$. 


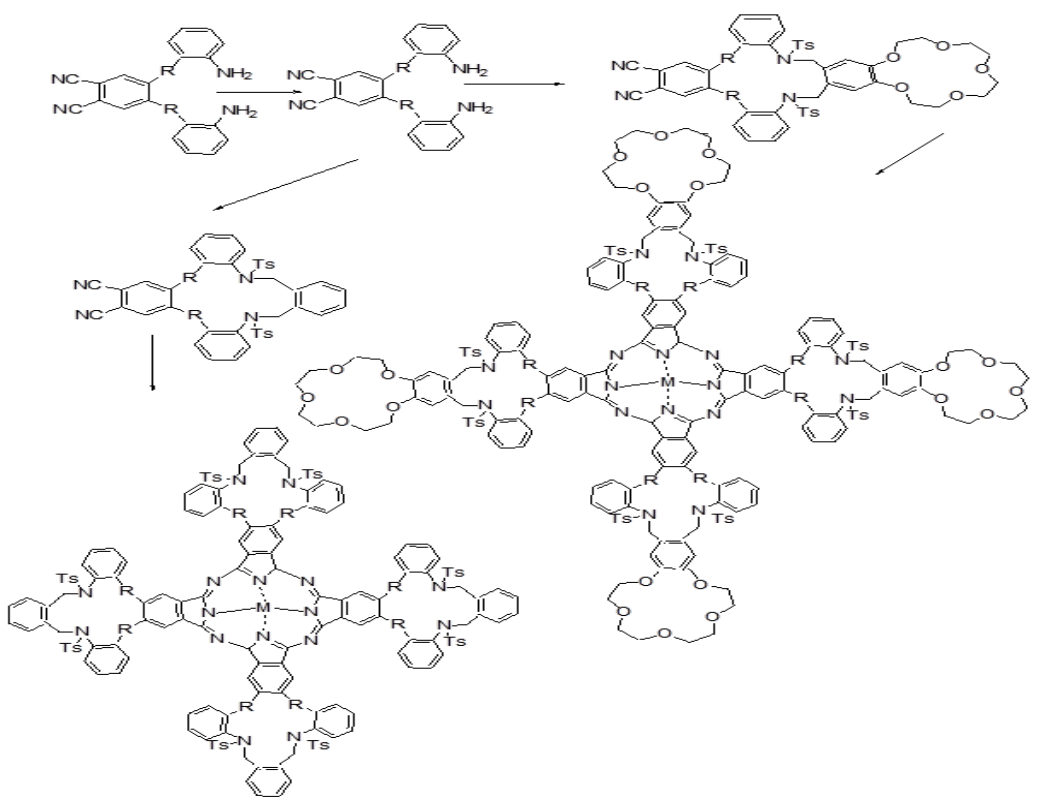

Scheme 17. Route of the synthesis of ligand and their complexes<smiles></smiles>

Fig. 17a. Preparation og di-amino 18-crown-16<smiles>[R]C=O</smiles><smiles>[R]C=Nc1ccc2c(c1)OCCOCCOc1ccc(N=C[R])cc1OCCOCC2</smiles>

Fig. 17b. Synthesis of crown ether azomethine holding DB18C6<smiles>Oc1ccccc1/N=C/c1ccc2c(c1)OCCOCCOCCOCCO2</smiles><smiles>Oc1ccc(Br)cc1/N=C/c1ccc2c(c1)OCCOCCOCCOCCO2</smiles><smiles>Oc1ccc(Cl)cc1/C=N/c1ccc2c(c1)OCCOCCOCCOCCO2</smiles><smiles>Oc1cc2ccccc2cc1N=Cc1ccc2c(c1)OCCOCCOCCOCCO2</smiles>

Fig. 18. The structures of synthesized Schiff base ligands

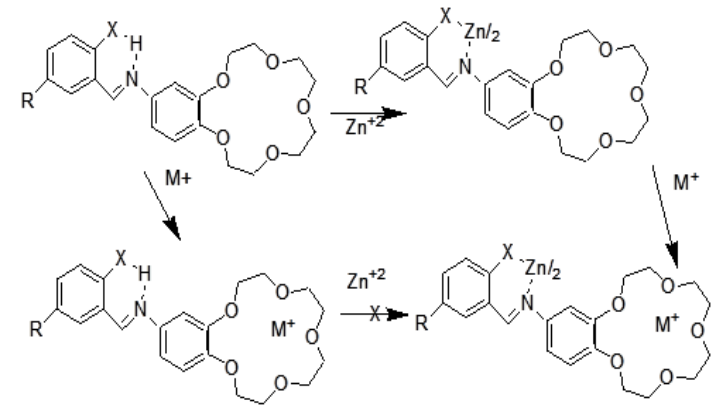

Scheme 18. Synthesis of crown ether Schiff base and their complexes

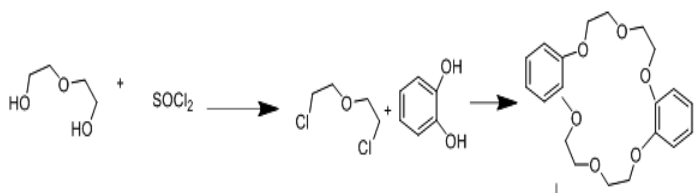<smiles>O=Cc1ccccc1O</smiles><smiles>COCCOc1cc(N)cc(OCCOCCO)c1</smiles><smiles>Oc1ccccc1N=Cc1ccc2c(c1)OCCOCCOc1cccc(c1)OCCOCCO2</smiles>

Scheme 19. The Route of synthesis of crow ether Schiff base 
<smiles>Oc1ccccc1/C=N/c1ccc2c(c1)OCOCOc1cc(/N=C/c3ccccc3O)ccc1OCCOCCO2</smiles>

Fig. 19. The structure of double arms Schiff base ligand

Azomethine ligands of 4-antipyrine and their complexes have a variety of applications in the biological, medical, analytical and pharmacological areas. Although bi-dentate chelating compounds were investigated in plentiful studies, only one of them has been reported on benzo crown ether-4-antipyrine containing Schiff base group. Regarding this property, Hayvali ${ }^{80}, 2009$, reported the preparation of a novel crown antipyrine azomethine (Figure 20).

In the same way, Hayvali et al., 2003, reported the synthesis of four novel-15-crown-5 ether ligands display different ortho-hydroxy Schiff base type horizontal function (Fig. 21). The synthesized Schiff base containing Crown ether moiety was characterized using different analysis methods ${ }^{81}$.

More work was done by Guler and Hayvalis2, they reported the preparation of novel benzyloxybenzaldehyde derivatives by the condensation of 4-benzonitrile with vanillin, o-vanillin, 2-hydroxy-4-methoxy-benzaldehydeand 2-hydroxy5-methoxybenzaldehyde (Scheme 20 and 21).

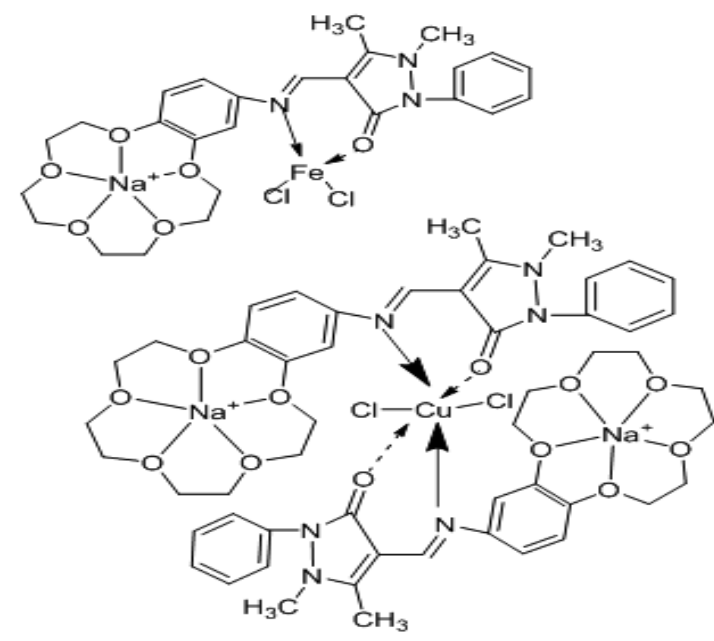

Fig. 20. Suggested structure of the azomethine ligands and their complexes<smiles>[R]N=Cc1cc(OCCOCCOCCOCCO)c(O)cc1O</smiles>

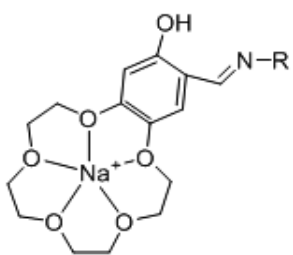<smiles>[R]=C=CC=NC(=C)C</smiles><smiles>[R]=[Fe]</smiles><smiles>Cc1ccnc(C)c1</smiles><smiles>CCc1ccco1</smiles><smiles>Cc1ccnc(C)c1</smiles>

Fig. 21. Crown compounds and complexes

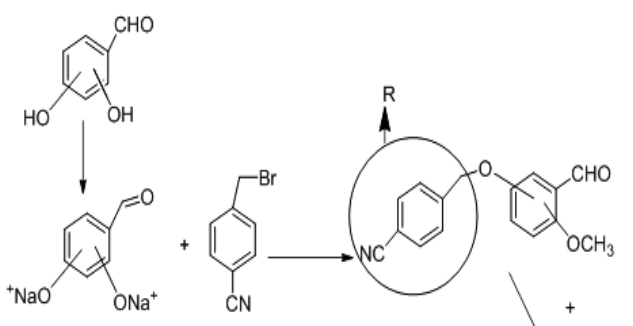

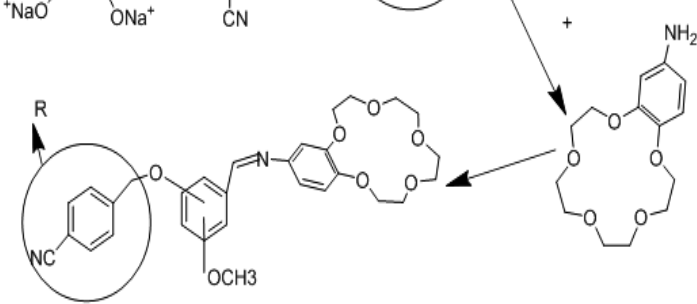
Scheme 20. Skeleton of the aldehydes with the crown azomethine

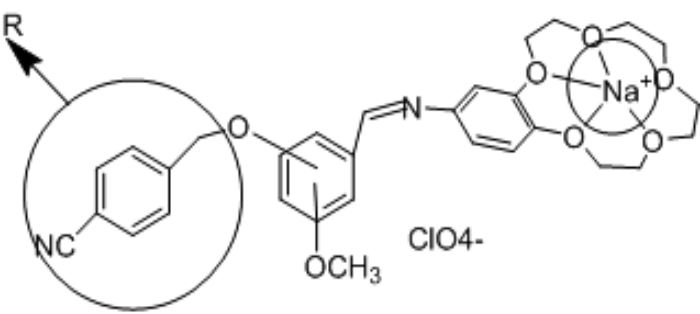

\section{Scheme 21. Suggested structures of complexes}

Fernando and his team 2011, has been successfully prepared di-metallated crown azomethine Palladacycles complexes (Fig. 22). They tried to use tetradentate $[\mathrm{C}, \mathrm{N}, \mathrm{N}, \mathrm{C}]$ crown ether azomethine to prepare di-cyclo-metallated complexes having a polymeric Skeleton. Furthermore, the activity of such ligands toward tertiary mono- and diphosphines have been tested orderly to detect new, and full of hope unforeseen, results ${ }^{83}$. 
<smiles>C(=N/c1ccc2c(c1)OCCOCCOCCOCCO2)\c1ccc(/C=N/c2ccc3c(c2)OCCOCCOCCOCCO3)cc1</smiles>

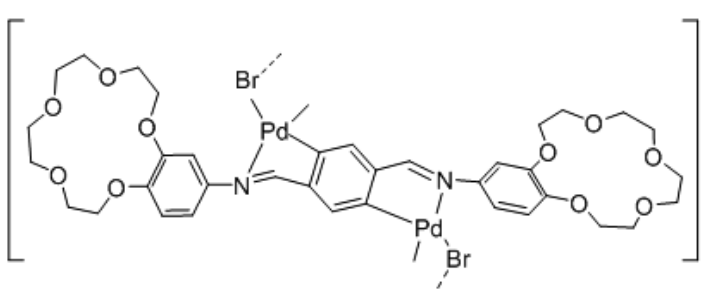

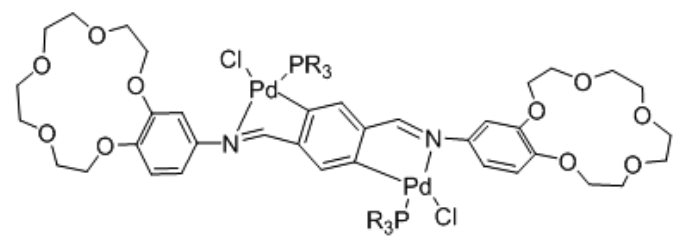

Fig. 22. The structure of synthesized cyclopalladated compounds

A novel set of poly Schiff base containing semi-hard big macrocycle in the major branched (bis-5-aldoxy-1,3-phenylene-32-crown-10) has been prepared in one pot of reaction ${ }^{84}$. A direct poly condensation reaction of bis-5-aldoxy-1, 3-phenylene-32-crown -10 in DMF produced a great Molecular weight poly crown azomethine compounds (Scheme 22)

$\mathrm{N}$-(4'-benzo-15-crown-5-ether)-anthracene -9-imine as crown azomethine was synthesized by $\mathrm{Bae}^{85}$ et al., 2001 and used it as a neutral transporter for ion electric-electrode to locate potassium by potentiometry (Figure 23).

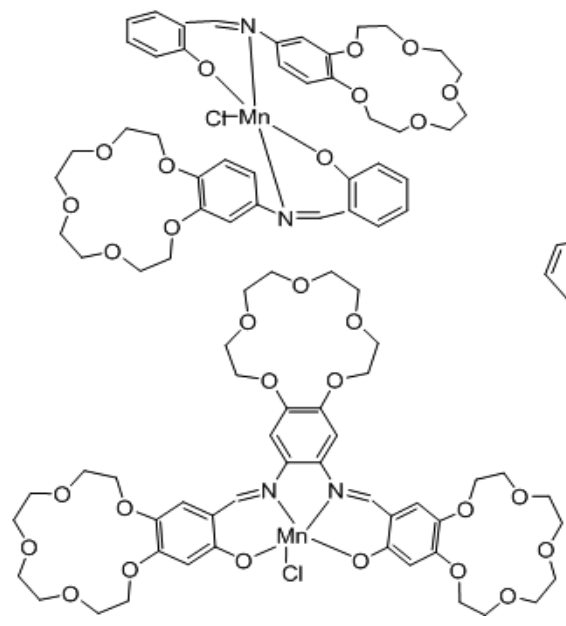<smiles>O=Cc1cc(O)cc(C=O)c1</smiles>

Scheme 22. The route of synthesis of poly crown ether Schiff base<smiles>O=C(Nc1ccc2c(c1)OCCOCCOCCOCCO2)c1cc([N+](=O)[O-])cc([N+](=O)[O-])c1</smiles><smiles></smiles>

Fig. 23. Structures of 15-crown-5 derivatives used in this work

Four novels $\mathrm{Mn}$ (III) complexes with a crown containing salicylaldimine azomethine ligand have been successfully prepared ${ }^{86}$ and utilized as design to imitate hydrolase in the hydrolysis of 4-nitrophenylpicolinate (PNPP). The kinetics and mechanism of catalytic PNPP hydrolysis have been studied. The results signalize that the crown azomethine metal complexes appeared more catalytic power compared with complexes without crown ether Schiff base (Figure 24).

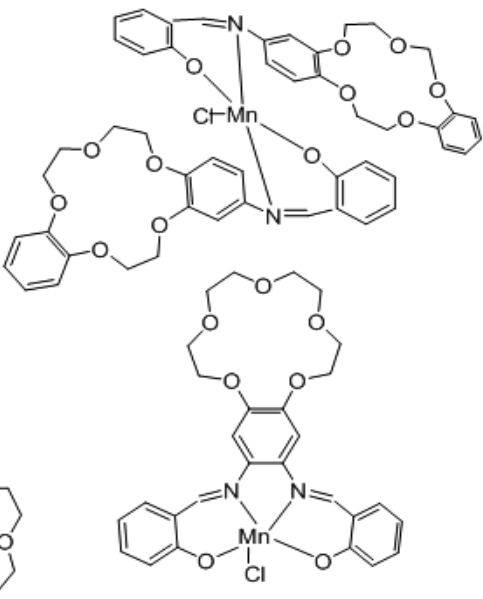

Fig. 24.The structure of manganese(III) complexes 
Condensation of 4-aminobenzo-15-crown-5 with aromatic aldehydes created novel stable of crown ether azomethine ligands. Sadoveskaya ${ }^{87}$ et al., 2015, synthesized novel ligands containing crown azomethine. The prepared ligands were identified using several analysis methods (Scheme 23).

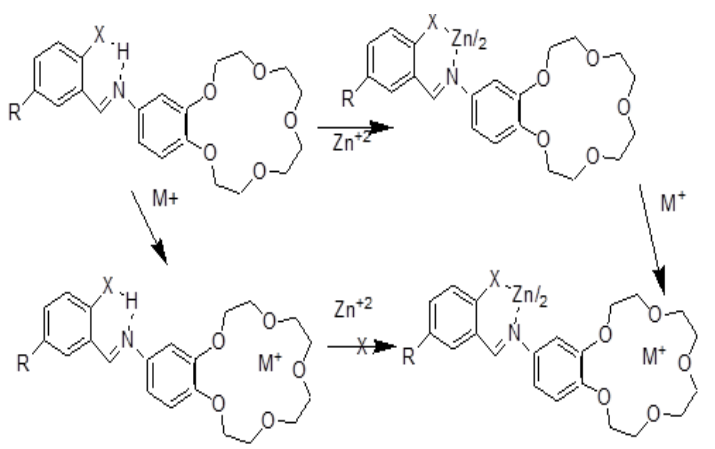

Scheme 23. Synthesis of crown ether Schiff base and their complexes
Novel crown ether azomethine from an $\mathrm{N}$-salicylidenaniline compound with 15-crown-5 moiety, was prepared ${ }^{88}$. Coordination of prepared ligands with some metal ion with $\mathrm{Na}^{+}$or/and $\mathrm{Zn}^{+2}$ encourage evident changes in fluorescence spectra. Crown ether moiety after chelating with metal ion, the electron-rich metals in crown moiety will be coordinated. Hence, the PET action from crown giver across the fluorophore is closed and high fluorescence will be formed (Scheme 24 and 25).

Moutet ${ }^{89}$ et al., 2001, synthesized novel ligands containing azomethine moiety as a redox center and a crown-ether-like segment as a chelating site. These complexes produced from matrix combine of bi compartmental macrocyclic compounds with one tough and one smooth gap, formed by condensation of asemicarbazide with a linear polyether aldehyde in the presence of metal cation (Scheme 26).<smiles>COc1cc(/C=N/c2ccccc2)cc(OCCOCCOCCOCCO)c1</smiles>

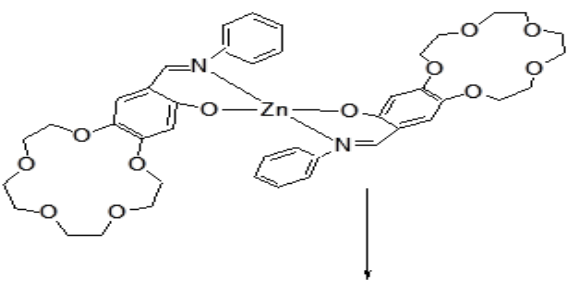

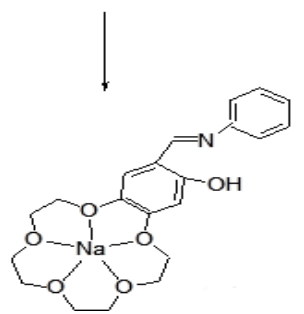

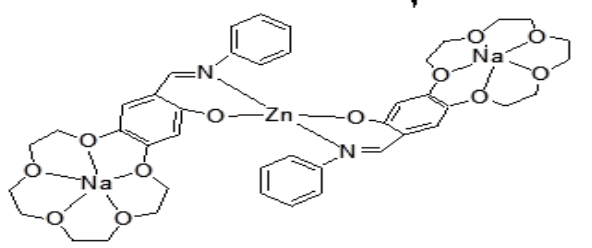

Scheme 24. The molecular structutes of ligand and their complexes with $\mathrm{Na}+$ and $\mathrm{Zn+2}$

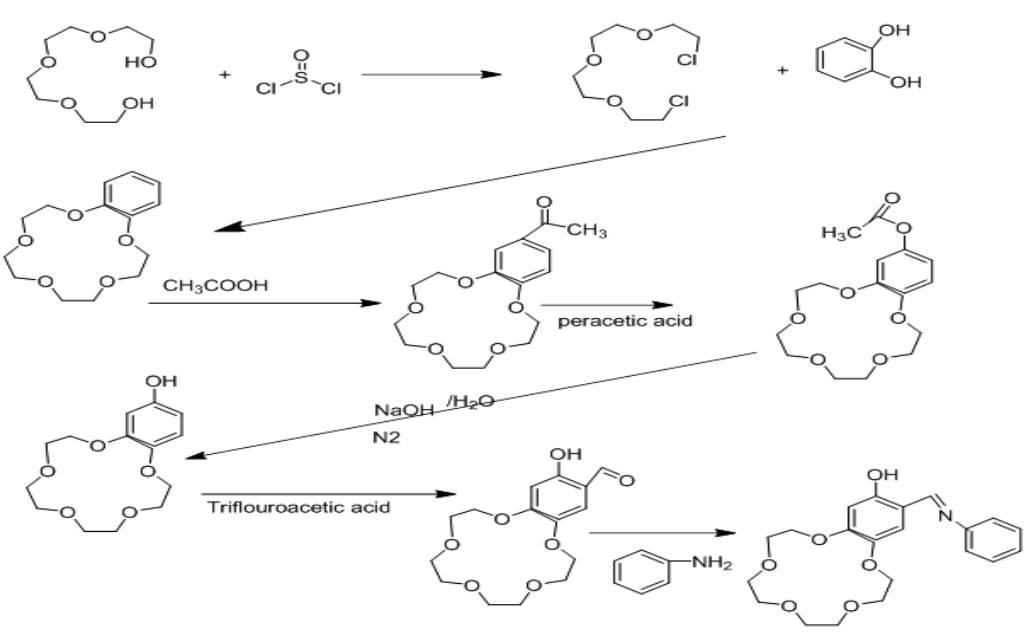

Scheme 25. The preparation route of compounds 


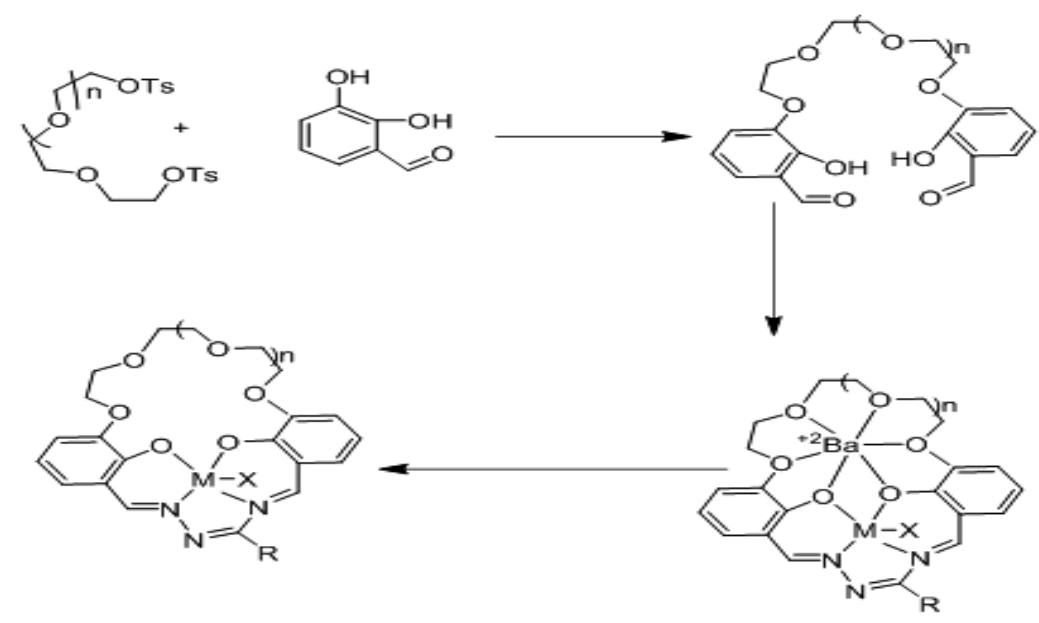

Scheme 26. Synthetic scheme of the preparation of receptors

\section{CONCLUSION}

Aza-crown ether Schiff bases have been used closely in synthesis of chelating ligands. crown ether containing azomethine groups are famed to join base metal ions in the crown ether hole notwithstanding the chelating of a transition metal focus through the $\mathrm{NO}$ donor atom. crown ether ligands with extra donor atom in the side chain have been prepared orderly to vary the ion bonding capability, sensitivity and selectivity of the origin crown ethers. Crown ethers along with Schiff base draw much consideration of coordination chemists. Collection of these fractions in one molecule superiority to ambis-dentate chelating systems able to figuration of both coordinate with $d$ metals of intermediate hardness $\left(\mathrm{Ni}^{+2}, \mathrm{Zn}^{+2}, \mathrm{Cu}^{+2}\right)$ coordinating via the azomethine part and crown ether complexes with toughs s-metal ions $\left(\mathrm{Li}^{+}, \mathrm{K}^{+}, \mathrm{Na}^{+}, \mathrm{Ba}^{2+}\right)$.

\section{ACKNOWLEDGEMENT}

Authors are thankful to the Faculty of Science, Department of Chemistry, University of Zakho for providing all facilities.

\section{REFERENCES}

1. Steed, J.W.; Turner, D. R.; Wallace, K. J.; Core concepts in supramolecular chemistry and nanochemistry. Hoboken, NJ: John Wiley \& Sons., 2007.

2. Liu, Y.; Han, J.-R.; Zhang, H.-Y.; Supramol. Chem., 2004, 16, 247.

3. Silverio, C.; Carlos, C.; Pablo, E.; Jean-Louis, G.; Daniel, G.; Bertrand, D.; Eur. J. Inorg. Chem., 2008, 8, 1210.

4. Faridbod, F.; Ganjali, M.R.; Dinarvand, R.; Norouzi, P.; Riahi, S.; Sensors., 2008, 8, 1645.

5. Gokel, G.W.; Leevy, W.M.; Weber, M.E.; Chem. Rev., 2004, 104, 2723.

6. Fery-Forgues, S.; Al-ali, F.; Photochem. J.; Photobiol. C: Photochem. Rev., 2004, 5, 139.

7. Chandra, S.; Gupta L.K.; Spectrochim. Acta., 2004, 60A, 1563.

8. Boojar, M.M.A.; Shockravi, A.; Bioorg. Med. Chem., 2007, 15, 3437.
9. Liu Y.; Tetrahedron Lett., 2007, 48, 3871.

10. Castro-Juiz, S.; Andez, A. F.; opez-Torres, M. L; Azquez-Garcı'a, D. V.; Suarez, A. J.; Vila, Jose M., and. Fernandez, Jesus J; Organometallics., 2009, 28, 6657.

11. Bren, V.A.; Usp. Khim., 2001, 7O(12), 1152.

12. Nelsen, D. L.; Wheit, P. S. and Gagne, M. R.; Organometalics., 2005, 24, 5479-5453.

13. Tsivadze, A.Yu.; Usp. Khim., 2004, 73,1,6.

14. Li, J. Z.; Xu, B. F., ZHOU F.M.; QIN, B., Yingb S.; Chinese Journal of Chemistry., 2007, 25, 1681-1685.

15. Hernandez-Molina, R. and Menderos, A.; Comprehensive Coordination Chemistry, McCleverty, J. A. A. and Meyer T. Y.; Eds., Amsterdam, Elsevier., 2003, 1, 411.

16. Garnovskii, A.D. and Vasil'chenko, I.S.; Usp. Khim., 2005, 74(3), 211. 
17. Arion, V.B.; Kravtsov, V. Ch.; Gradinaru, J.I.; Simonov, Y.A.; Gerbeleu, N.V.; Lipkowski, J.; Wignacourt, J.-P.; Vezin, H. and Mentre, O.; Chim. Acta., 2002, 328(1), 123.

18. Uraev, A.I.; Nefedov, S.E.; Dorokhov, A.V.; Borisenko, R. N; Vasil'chenko, I.S.; Garnovskii, A. D and Tsivadze, A.Yu.; Ross. Khim. Zh., 2004, 48(1), 38.

19. Gloe, K.; Graubaum, H.; Wust, M.; Rambusch, T.; Seichter, W.; Coord. Chem. Rev., 2001, 222, 103.

20. Valeur, B.; Leray, l.; Coord. Chem. Rev., 2000, 205, 3.

21. Hayvali, Z; Transition Met. Chem., 2009, 34, 97.

22. Hayvali.Z.;Raman, N.;Thangaraja, C.;Johnsonraja S.; Cent Eur J Che., 2005, 3(3), 537.

23. Steed, J.W.; Coord. Chem. Rev., 2001, 215, 171.

24. (a) K. M. C.; Lu, X. X.; Cheung, K. K.; Zhu, N. Chem., Eur. J., 2002, 8, 4066. (b) Breccia, P.; Van Gool, M.; Perez-Fernandez R.; MartínSantamaría, S.; Gago, F.; de Mendoza Prados, P.; J. J. Am. Chem. Soc., 2003, 125, 8270.

25. Tuntulani,T.; Poompradub, S.; Thavornyutikarn, P.; Jaiboon, N.; Ruangpornvisuti, V.; Chaichit, N.; Asfaric Z. and Vicensc, J.;Tetrahedron Letters., 2001, 42, 5541-5544.

26. Siu, P. K. M.; Lai, S. W.; Lu, W.; Zhu, N.; Che, C. M. Eur. J. Inorg. Chem., 2003, 27, 49.

27. Nakabayashi, T.; Ishida, T. and Nogami, T.; Inorg. Chem. Commun., 2004, 7, 1221.

28. Yoon, I.; Goto, M.; Shimizu, T.; Lee, S. S. and Asakawa, M.; J. Chem. Soc., Dalton Trans., 2004, 10, 1513.

29. Garnovskii, A.D. and Vasil'chenko, I.S.; Usp. Khim., 2002, 71(11), 1064.

30. Breccia, P.; Van Gool, M.; Perez-Fernandez, R.; Martín-Santamaría, S.; Gago, F.; Prados, P.; de Mendoza, J. J. Am. Chem. Soc., 2003, 125, 8270.

31. Garnovskii, A.D.; Vasilchenko, I.S.; Garnovskii, D.A.; and Kharisov, B.I; J. Coord. Chem., 2009, 62(2), 151.

32. Garnovskii, A.D.; Sadimenko, A.P.; Vasilchenko, I.S.; Garnovskii, D.A.; Sennikova, E.V.and Minkin, V.I.; Adv. Heterocycl. Chem., 2009, 93, 291.

33. Metelitsa, A.V.; Burlov, A.S.; Bezuglyi, S.O.; Borod kina, I.G.; Bren, V.A.; Garnovskii, A.D. and Min- kin V.I.; Koord. Khim., 2006, 23(12), 894.

34. You, Y. and Park, Y.; J. Chem. Soc., Dalton Trans., 2009, 12, 67.

35. Zhang, L.; Jiang, F.; Zhou, Y.; J. Coord. Chem.,
2009, 62(9) 1476.

36. Burlov, A.S.; Uraev, A.I; Ikorskii, V.N.; Nikolaevskii, S.A.; Koshchienko, Vasilchenko, Yu.V.; Garnovskii, I.S.; Vlasenko, D.A.; Zubavichus V.G.; Ya.V.; Divaeva, L.N; Borodkin. G.S. and Garnovskii, A.D.; Zh. Obshch. Khim., 2008, 78(6), 1002.

37. Garnovskii, A.D.; Vasilchenko, I.S.; Garnovskii, D.A.; Burlov, A.S. and Uraev, A.I. Ross. Khim. Zh., 2009, 53(1), 199.

38. Gibson, V.C. and Spitzmesser, S.K.; Chem. Rev., 2003, 103(2), 283.

39. (a) Dillon, R. E. A.; Stern, C. L.; Shriver, D. F. Solid State Ionics, 2000, 133, 247. (b) Yam, V. W. W.; Tang, R. P. L.; Wong, K. M. C.; Lu, X. X.; Cheung, K. K.; Zhu, N. Chem.; Eur. J., 2002, 8, 4066.

40. Burgette and S.C. and Lippard, S.J.; Coord. Chem. Rev., 2001, 334, 216-217.

41. Bren, V.A.; Dubonosov, A.D.;Tsukanov, A.V and Minkin, V.I.; Ross. Khim. Zh., 2009, 53(1), 42.

42. Whittell, G.R. and Manners, J.; Adv. Mat., 2007, 19, 3439.

43. Raman, N.; Kulandaisamy, A.; Shunmug asundaran, A.; Transit Met Chem., 2001. 26,131 .

44. Ismail, K. Z.; Transit Met Chem., 2000, 25, 522.

45. Raman, N.; Kulandaisamy, A.; Thangarajan, C.; Transit Met Chem., 2004, 29, 129.

46. Agarwal, R. A.; Singh, L.; Sharma K.; Bioinorg, Chem Appl., 2006, 1, 135.

47. Hayvali, Z.; Hayvali, M.; Kilic, Z.; Hokelek, T.; J Mol Struct., 2001, 597, 223.

48. Wei, X.; Mao, Z.; and Qin, S.; Synthetic Communications., 2004, 34(7), 1237-1246.

49. Lu, X. X.; Qin, S. Y.; Zhou, Z. Y.; Yam V. W. W.; Inorganica Chimica Acta., 2003, 346, 49-56.

50. Li, J. Z.; Wei, L.; Feng, F. M.; Transition Met. Chem., 2010, 35, 463-468.

51. Li, J.Z.; Yan, J.; Wei, X.; Zhou B. and Qin, S.Y.; Journal of Chemical Research., 2006, 7, 467-469.

52. Wei. Z.; Li, H. B.; Xiang R. li.; Wei, X.Y., Chinese Journal of Chemistry., 2003, 21, 510-514.

53. Wei, X.Y., Mao, Z. H.; Li, J. Z.; Qin S. Y.; Acta Chimica Sinica., 2004, 62(10), 969-974.

54. Li, J. Z.; Lu, Y.; Wei, L.; Hu, W. and Qin, S. Y.; Progress in Reaction Kinetics and Mechanism., 2010, 35, 368-386. 
55. Wei, X.Y.; Li, J. Z.; Mao, Z. H.; Zhou B.; Qin S. Y.; Chinese Journal of Chemistry., 2004, 22, 558-562.

56. Antonova, L.; Vladimirova, M.; Stanoeva, E.; Fabian, W. M. F.; Balleste L. and Mitewa M.; Journal of Inclusion phenomena and Macrocyclic Chemistry., 2001, 40, 23-28.

57. Li, J. z.; Xu, B.; wang, y. and Li, S. X.; Transition Metal chemistry., 2006, 31, 487-494.

58. Khandar, a. A.; Yazdi, s. a. h.; Khatamian, M.; McArdle, P.; Zarei, A.; Polyhedron., 2007, 26, 33-38.

59. Cupta, V. k.; pal, m. j.; Singh, A. k.; Analytica Chimica Acta., 2009, 631, 161-169.

60. Isaad, j.; El Achari, A.; Analyst., 2013, 138, 3809-3819.

61. Zeng, wei.; mao, Z.; Wei, X.; Li, J.; Hong, Z. and Qin, S.; Journal of Supramolecular Chemistry., 2002, 2, 501-507.

62. Zeng, W.; li, J.; Qin, S.; Inorganic Chemistry communications., 2006, 9, 10-12.

63. Li, J. Z.; Wang, Y.; Zeng, W.; Qin, S. Y.; Supramolecular Chemistry., 2008, 20(3), 249-254.

64. Zeng, W.; Li, J.; Mao, Z.; Hong, Z.; Qin, S.; Adv. Synth. Catal., 2004, 346, 1385-1391.

65. Li, J. Z.; Li, S. X.; Xie, F.; Transition Metal Chemistry., 2006, 31, 1066-1070.

66. Yan, j.; Li, J. Z.; and Li, Kc. B.; Transition Metal Chemistry., 2006,31, 286-292.

67. Mizyed S.; Kiwan R. and Marji D.; Jordan Journal of Chemistry., 2013, 8(2), 71-78.

68. Wei, X.; Li, J.; Zhou, B.; Qin, S.; Transition Metal Chemistry., 2004, 29, 457-462.

69. Sousa, C.; Gamerio, P.; Freire C.; De Castro, B,; Polyhedron., 2004, 23, 1401-1408.

70. Li, J. Z.; Feng, F. M.' Xu, B., Transition Metal Chemistry., 2008, 33, 655-660.

71. Li J. Z.; Feng F. M.; Zang J.; and Quin S. Y.; Journal of Dispersion Science and Technology., 2011, 32, 14-22.

72. Hu W.; Li J.; Jin Z.; J.; Wang Y.; Zou L.; Du J.; and Wang X.; Journal of Dispersion Science and Technology., 2010, 31, 529-535.

73. Li J. Z.; Xie J. q.; Zeng W.; Wei X. Y.; Zhou B.; Zeng X. C.; and Qin S. Y.; Transition Metal
Chemistry., 2004, 29, 488-494.

74. Seyedi S.M.; Gholam Hossein Zohuri G. H.; and Sandaroos R.; Supramolecular Chemistry., 2011, 23(7), 509-517.

75. Kandaz, M.; Yılmaz I.; Bekaroglu O.; Polyhedron., 2000, 19, 115-121.

76. Parikh V. B. And Menon, S. K.; Mol. Cryst., 2008, 482, 71-83.

77. Burlov, A.S.; Tsukanov, A.V.; Borodkin, G.S.; RevinskiiYu.V.; Dubonosov, A.D.; Bren, V.A.; Garnovskii A.D.; Tsivadze, A.Y.; Minkin, V.I.; Russian Journal of General Chemistry., 2006, 76(6), 992-996.

78. Safin D. A.; Robeyns K.; Garcia Y.; Gryst Eng Comm., 2012, 14, 5523-5529.

79. Jogani, S. K.; Menon S. K.; Agrawal, Y. K.; Synth. React. Inorg. Met.-Org. Chem, 2000, 30(7), 1317-1329.

80. Hayvali Z.; Transition Met. Chem., 2009, 34, 97-101.

81. Hayvali Z.; Hayvali M.; Kilic Z.; Kokelek T. and Weber E.; Journal of Inclusion Phenomena and Macrocyclic Chemistry., 2003, 45, 285-294.

82. Güler H.; Hayvali Z.; Dal H.; Hökelek T.; Polyhedrone., 2012, 31,688-696.

83. Fernandz A.; Margarita Lopez-Torres; Samuel Castro-Juiz; Manuel Merino; Digna VazquezGarcia; Josa M. Vila and Jesus J. Fernandez; Organometallics., 2011, 30, 386-395

84. Duta P. K.; Indian journal of Chemical Technology., 2001, 8, 515-517.

85. Bae, Z. U; Lee S. B.; Chang S. H. and Kim U. R.; Journal of Korean chemical Society., 2001, 45(1), 31-39.

86. Li J. Z.; Xu b. and Li S. X.; Transition Metal Chemistry, 2005, 30, 669-676.

87. Sadovskaya, N. Yu; Glushko, V. N.; Retivov, V. M.; Belus, S. K. and Grokhovskii V. V.; Russian Journal of General Chemistry., 2015, 85(12), 2771-2777.

88. Zhao L.; Chen X., Guo F., Gou B.; Yang C. and Xia W; Journal of Luminescence., 2014, 145, 486-491.

89. Moutet J. C.; Aman E. S., U E. M.; arion V.; Gerbeleu N.; Revenco M.; Electrochimica Acta., 2001, 46, 2733-2740. 